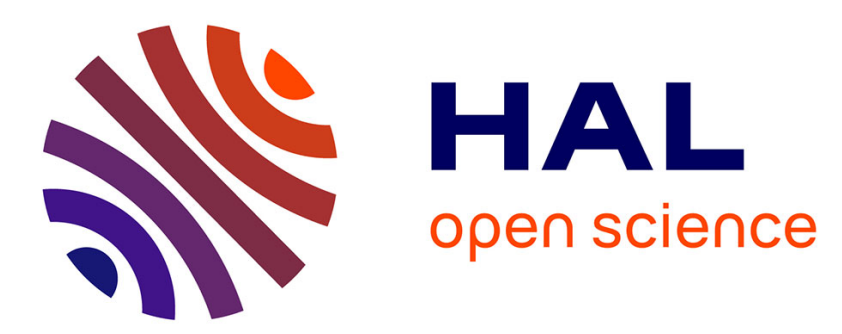

\title{
Physical and biological response of the Arabian Sea to tropical cyclone Phyan and its implications
}

\author{
P. Byju, S. Prasanna Kumar
}

\section{To cite this version:}

P. Byju, S. Prasanna Kumar. Physical and biological response of the Arabian Sea to tropical cyclone Phyan and its implications. Marine Environmental Research, 2011, 10.1016/j.marenvres.2011.02.008 . hal-00703489

\section{HAL Id: hal-00703489 \\ https://hal.science/hal-00703489}

Submitted on 2 Jun 2012

HAL is a multi-disciplinary open access archive for the deposit and dissemination of scientific research documents, whether they are published or not. The documents may come from teaching and research institutions in France or abroad, or from public or private research centers.
L'archive ouverte pluridisciplinaire HAL, est destinée au dépôt et à la diffusion de documents scientifiques de niveau recherche, publiés ou non, émanant des établissements d'enseignement et de recherche français ou étrangers, des laboratoires publics ou privés. 


\section{Accepted Manuscript}

Title: Physical and biological response of the Arabian Sea to tropical cyclone Phyan and its implications

Authors: P. Byju, S. Prasanna Kumar

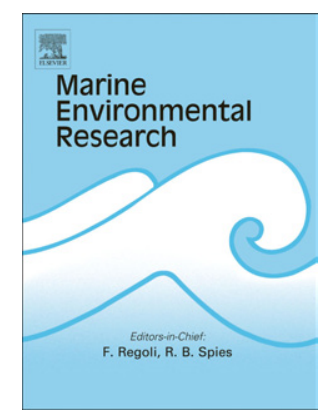

PII:

S0141-1136(11)00035-3

DOI:

10.1016/j.marenvres.2011.02.008

Reference: MERE 3514

To appear in: Marine Environmental Research

Received Date: 31 May 2010

Revised Date: 25 February 2011

Accepted Date: 25 February 2011

Please cite this article as: Byju, P., Prasanna Kumar, S. Physical and biological response of the Arabian Sea to tropical cyclone Phyan and its implications, Marine Environmental Research (2011), doi: 10.1016/ j.marenvres.2011.02.008

This is a PDF file of an unedited manuscript that has been accepted for publication. As a service to our customers we are providing this early version of the manuscript. The manuscript will undergo copyediting, typesetting, and review of the resulting proof before it is published in its final form. Please note that during the production process errors may be discovered which could affect the content, and all legal disclaimers that apply to the journal pertain. 
1 Physical and biological response of the Arabian Sea to tropical cyclone Phyan

2 and its implications

3

4 P. Byju and S. Prasanna Kumar*

5 National Institute of Oceanography (CSIR), Dona Puala, Goa-403 004, India

6

7

8

9 P. Byju : byjupbhaskar@gmail.com

10 S. Prasanna Kumar : prasanna@nio.org

11

12

13

14 *Corresponding Author:

15

16

17 National Institute of Oceanography

18 Dona-Paula, Goa-403004, India.

19 Tel: +91(832) 2450300

20 Fax: +91(832) 2450608

21

22

23 


\section{5 and its implications}

P. Byju and S. Prasanna Kumar*

28 National Institute of Oceanography (CSIR), Dona Puala, Goa-403 004, India

$29 *$ Corresponding author

31 Abstract.

32 The response to the tropical cyclone Phyan, which developed in the eastern Arabian Sea during

33 9-11 November 2009, was rapid cooling of sea surface temperature (SST), enhancement of 34 chlorophyll $a$ and two-fold increase in net primary productivity (NPP). Cooling of SST was 35 immediate in response to the strong wind mixing, and the subsequent upward Ekman-pumping 36 sustained the cooling even after the dissipation of Phyan. The biological response mediated by 37 the upward Ekman pumping driven vertical transport of subsurface nutrient showed a time lag of 38 3-4 days. The $\mathrm{CO}_{2}$ flux to the atmosphere associated with Phyan was $0.123 \mathrm{Tg} \mathrm{C}$, which 39 accounted for $\sim 85 \%$ of the total out-gassing from the eastern Arabian Sea during November.

40 Thus, an increased occurrence of cyclones in a warming environment will lead to an enhanced

41 biomass production and also increase in $\mathrm{CO}_{2}$ out-gassing.

42 Key words: Tropical cyclone, Arabian Sea, Sea surface temperature, Ekman-pumping, Wind43 mixing, Chlorophyll, Primary production, $\mathrm{CO}_{2}$ out-gassing, Biogeochemical cycle, Nutrients.

\section{1. Introduction}

The global tropical cyclone statistics shows that only about $7 \%$ of tropical storms form in the north Indian Ocean (comprising of the Bay of Bengal and the Arabian Sea) and, compared to the

49 Bay of Bengal, the ratio of the frequency of occurrence of tropical cyclones over the Arabian Sea 50 is about 4:1 (Dube et al., 1997). Though this number appears to be small in the context of global 51 occurrence, they cause far more damage and misery to the adjoining Asian continent which

52 houses a quarter of humanity most of whom live in the low-lying coastal plain. In the Arabian 53 Sea, tropical cyclones form predominantly during pre-monsoon/spring-summer transition (May54 June) and post-monsoon/fall-winter transition (October-November) periods.

55 The sun heats the ocean surface and the water evaporates over the hot ocean surface, while it 56 condenses in the atmosphere as it rises. If the heating and evaporation is intense, the condensing 
57 air releases a large quantity of latent heat, which is the necessary fuel for the development and

58 intensification of a cyclone. So in a warming environment it is expected that the frequency and

59 severity of tropical cyclones will also increase (Trendberth, 2005; Emanuel, 2005; Webster et al.,

60 2005). However, factors other than sea surface temperature (SST), such as vertical wind shear,

61 and relative humidity have been cited for their role in regulating cyclone characteristics as well

62 as its genesis (Gray, 1979). It has been reported that the Arabian Sea warmed by about $0.5^{\circ} \mathrm{C}$

63 during 1904-1994 (Rupakumar et al., 2002). In a recent study Prasanna Kumar et al. (2009)

64 speculated that the Arabian Sea is experiencing a regional climate shift since 1995, which is

65 accompanied by a five-fold increase in the occurrence of the most intense cyclones. Even though

66 cyclones are known for their destruction of life and property on the land, they often augment life

67 in the ocean (Madhu et al., 2002; Subrahmanyam et al., 2002; Hema Naik et al., 2008; Rao et al.,

68 2006) through upward pumping of nutrients into the euphotic zone. Thus, in a warming scenario,

69 the Arabian Sea could become more productive (see Goes et al., 2005; Prasanna Kumar et al.,

70 2010), which has implications for regional biogeochemistry. For example, increased biological

71 productivity will exert pressure on the already existing mid-depth oxygen minimum zone (OMZ)

72 in the central Arabian Sea and the severe hypoxia experienced along the eastern Arabian Sea

73 (Naqvi et al., 2000). Studies have shown that the Arabian Sea is a perennial source of ocean to

74 atmosphere $\mathrm{CO}_{2}$ flux in all seasons (Goyet et al., 1998; Sarma et al., 1998; Sabine et al., 2000)

75 and strong wind can increase the flux. It is in this context that we present the upper ocean

76 response of the eastern Arabian Sea to the tropical cyclone Phyan and its impact on biological

77 productivity.

\section{2. Materials and methods}

\subsection{Data}

It is very difficult to carry out ship borne observations during violent atmospheric processes

84 like cyclones with great variation in trajectory and strength. With the advent of the satellite era, 85 remote sensing satellites with radiometers at visible, infra-red and microwave frequencies 86 provide a real-time recognition and diagnosis of tropical cyclone development. But ocean colour 87 sensors are obscured by clouds, which are often present during and after the passage of a 88 cyclone, therefore it can capture only a very small part of the entire event. In the present study 89 the track of the cyclone was taken from the Indian Meteorological Department (IMD) 
91 Optimally Interpolated sea surface temperature (SST) from the remote sensing satellites Tropical

92 Rainfall Measuring Mission Microwave Imager (TMI), Moderate Resolution Imaging

93 Spectroradiometer (MODIS) and Advanced Microwave Scanning Radiometer-Earth observing

94 system (AMSR-E) (ftp://ftp.misst.org/ L4/mw_ir) with a spatial resolution of $9 \mathrm{~km}$, to elucidate

95 evolution of surface ocean thermal variation due to the cyclone. We also used 3-day composite

96 ocean colour data by NASA's MODIS-Aqua (http://oceandata.sci.gsfc.nasa.gov/MODISA/),

97 which captured only a part of the chlorophyll $a$ bloom patch because of the overcast sky. A

98 tropical cyclone releases its energy in the form of strong winds which are significant to ocean

99 mixing resulting in cooling, increased biological productivity and enhanced emission of $\mathrm{CO}_{2}$. A

100 blended wind product provided by IFREMER/CERSAT derived from the near-real-time

101 measurements by QuikSCAT and SSMI with a spatial and temporal resolution of $25 \mathrm{~km}$ and 6

102 hours respectively, was used for the calculation of Ekman pumping velocity. Since this data is

103 available only till $22^{\text {nd }}$ November 2009 (ftp://ftp.ifremer.fr/ifremer/cersat/products/gridded/ mwf-

104 blended/) we used data from NOAA's National Climatic Data Center,

105 (http://www.ncdc.noaa.gov/oa/rsad/ blendedseawinds.html) to calculate wind-dependent, gas-

106 transfer velocity for $\mathrm{TCO}_{2}$ flux for November 2009. We have also used the climatological sea-

107 air difference in partial pressure of $\mathrm{CO}_{2}$ (Takahashi et al., 2009a) to calculate total $\mathrm{CO}_{2}$ flux over

108 the eastern Arabian Sea before, during and after the passage of the cyclone.

109

\subsection{Developmental stages of Phyan}

The tropical cyclone formed during 9-11 November 2009 over the Arabian Sea, named as

113 'Phyan' by Indian Meteorological Department, had some special characteristics. A low pressure

114 system that initially formed over the Comorin area $\left(8.08^{\circ} \mathrm{N} \& 77.56^{\circ} \mathrm{E}\right)$ on $7^{\text {th }}$ November 2009

115 became well marked over Lakshadweep area $\left(10.57^{\circ} \mathrm{N} \& 72.62^{\circ} \mathrm{E}\right)$ on $8^{\text {th }}$ November (not shown

116 in Figure 1) and developed into a depression on $9^{\text {th }}$ November 2009 over the south-east Arabian

117 Sea centered at $11^{\circ} \mathrm{N}$ and $72^{\circ} \mathrm{E}$ (Figure 1). It moved initially in a north-northwesterly direction

118 till $10^{\text {th }}$ November and then re-curved to north-northeastward. It intensified into a deep

119 depression at 0830 hrs Indian Standard Time (IST) and into a cyclonic storm 'Phyan' at 2330 hrs

120 IST on $10^{\text {th }}$ November 2009 (see also Joseph et al., 2010). Continuing its north-northeastward

121 movement, the cyclonic storm 'Phyan' crossed the coast (near Mumbai, $18.98^{\circ} \mathrm{N} \& 72.83^{\circ} \mathrm{E}$,

122 Figure 1) between 1530 and 1630 hrs IST on 11th November causing a wide range of 
123 destruction. The central pressure and maximum sustained surface wind speed was estimated to

124 be $988 \mathrm{hPa}$ and $83 \mathrm{~km} /$ hour respectively during $11^{\text {th }}$ November 2009 . The maximum intensity of

125 'Phyan' was T 3.0 according to Dvorak's technique (http://www.ssd.noaa.gov/PS/TROP/CI126 chart.html).

\section{Results and discussions}

\subsection{SST response}

Tropical cyclones form in warm ocean water (Gray, 1979). Once formed the strong wind-stress curl associated with the cyclone drives the upward Ekman-pumping and the resultant entrainment and mixing cools the upper ocean (Price, 1981; Pudov, 1992; DeMaria and Kaplan, 1994; Sadhuram, 2004). Ocean thermal condition was well favoured for the genesis of cyclone Phyan in the eastern Arabian Sea with a SST in excess of $29.4^{\circ} \mathrm{C}$. To understand the thermal response of the upper ocean to the passage of Phyan, we plotted SST along the cyclone track. At each latitude along the track, the SST was averaged over 1 degree longitude and was plotted during 3 periods - before (6-8 November 2009), during (9-11 November 2009) and after (12-13 November 2009) the passage of the cyclone (Figure 2).

Before the passage of tropical cyclone Phyan the SST, in general, was in excess of $29.4^{\circ} \mathrm{C}$ at its 142 origin while it was $\sim 2^{\circ} \mathrm{C}$ colder towards the north (Figure 2). The colder condition in the north 143 (north of $17^{\circ} \mathrm{N}$ ) before the arrival of the cyclone was due to the winter cooling under the 144 influence of cold and dry winds of continental origin (Prasanna Kumar and Prasad, 1996). 145 During the formation and passage of the cyclone (9-10 November 2009), a strong surface 146 cooling of about $2^{\circ} \mathrm{C}$ was noticed. Cooling predominantly occurred between the latitude $11^{\circ} \mathrm{N}$ 147 and $14^{\circ} \mathrm{N}$ where the cyclone veered from north-west to north-east. Notice the cold pool to the 148 right of the cyclone track in Figure 1. Similar cooling at the right side of the cyclone track has 149 been reported earlier by several authors (Price 1981; Pudov, 1992; Sadhuram, 2004). Price 150 (1981) attributed this right-side bias of SST reduction to non-linear mixed-layer current response 151 and the stronger winds located on the right side of the storm track due to storm motion. In the 152 present study even after the passage of cyclone Phyan, the cooling of SST persisted in the south 153 up to $14^{\circ} \mathrm{N}$. In the north (north of $14^{\circ} \mathrm{N}$ ), however, the cooling of SST was gradual. To further 154 understand the mechanism of cooling and the occurrence of cold pool associated with the 155 cyclone Phyan, we calculated the wind-stress curl and the vertical velocity in a box EFGH (0.5- 
156 degree latitude $x$ 1-degree longitude) located within the cold pool (see Figure 1) during the first

157 fortnight of November. The value of wind-stress curl was near zero before the formation of

158 Phyan and it suddenly peaked during the period of cyclone (9-11 November 2010) with the

159 highest value of $7.5 \times 10^{-6} \mathrm{~N} / \mathrm{m}^{3}$ (Figure 3) on $10^{\text {th }}$ November. The vertical velocity also showed

160 a similar pattern with upward (negative) velocity during the period of cyclone. The highest

161 upward velocity of $2.4 \times 10^{-4} \mathrm{~m} / \mathrm{s}$ occurred on $10^{\text {th }}$ November which coincided with the time of

162 maximum strength of wind-stress curl. Note that the SST cooled from the pre-cyclone value of

$16329.9^{\circ} \mathrm{C}$ to $27.9^{\circ} \mathrm{C}$ on $11^{\text {th }}$ November 2010 . This time lag between the maximum strength of wind-

164 stress curl (and the vertical velocity) and the occurrence of the maximum cooling indicates the

165 thermal response time of the water column associated with diffusion. Though the wind stress curl

166 diminished rapidly after $10^{\text {th }}$ November when the cyclonic storm moved away from the cold pool

167 location, the momentum imparted by wind stress could sustain the upward transport of cold

168 water. This clearly indicated that the maximum cooling and hence the cold pool, at the right side

169 of cyclone track, was generated by the cyclonic wind-stress curl and the associated upward

170 Ekman-pumping. The enhanced evaporation under the influence of strong winds can also lead to

171 decrease in the SST, but its magnitude is much less (Price, 1981). The SST prior to the formation

172 of Phyan was $1^{\circ} \mathrm{C}$ higher than the climatological SST computed from TMI during 1998 to 2009.

173 This higher SST could be one of the factors that triggered the cyclone.

\section{3.2. Biological response}

\subsubsection{Enhancement of Chlorophyll a}

Biological response of the Arabian Sea to the passage of Phyan was explored by analyzing chlorophyll $a$ concentration during the first fort-night of November 2009 in the box ABCD (see Figure 1 for location). A major drawback of such a study is the lack of data during the peak of the cyclone activity over the ocean due to thick cloud associated with it. Since in situ measurements are extremely difficult in such violent condition and non-existent in the present case, we used the 3-day composite of chlorophyll $a$ concentration derived from MODIS-Aqua (Figure 4). The average chlorophyll $a$ concentration in the eastern Arabian Sea before the genesis of Phyan was $\sim 1.0 \mathrm{mg} / \mathrm{m}^{3}$. However, during its genesis, evolution and decay the chlorophyll $a$ concentration showed a rapid decline reaching almost $0.45 \mathrm{mg} / \mathrm{m}^{3}$. This is due to the spare data coverage by MODIS-Aqua because of thick cloud associated with the cyclone as indicated by the percentage of pixel count in Figure 4. During a relatively cloud-free condition the pixel count 

(3500) was more than $70 \%$. This declined to almost $2 \%$ (79 pixels) during the period of cyclone

191 activity (8-11 November 2009). After $11^{\text {th }}$ November when Phyan had dissipated, the chlorophyll $192 a$ concentration showed a continuous increase reaching an average highest value of $\sim 1.5 \mathrm{mg} / \mathrm{m}^{3}$ 193 (black dotted line in figure 4) on $16^{\text {th }}$ November. Note that the pixel count also showed an 194 increase which indicated the robustness of the chlorophyll estimate. A greater enhancement in 195 the chlorophyll $a$ concentration was seen on $16^{\text {th }}$ November at a location close to the Phyan 196 trajectory (e.g., $71.16^{\circ} \mathrm{E}, 16.66^{\circ} \mathrm{N}$ ), but away from the continental shelf, where the value reached 197 more than $6 \mathrm{mg} / \mathrm{m}^{3}$ (not presented here). This increased biomass seen 3-4 days after the 198 dissipation of tropical cyclone Phyan indicated the response of biology and the following is the 199 probable mechanism.

200 It is well known that the strong curling winds of cyclone can bring nutrients from the 201 subsurface to the surface by Ekman pumping and entrainment due to the wind stirring at the base 202 of the mixed layer (Subrahmanyam et al., 2002; Lin et al., 2003). An analysis of the monthly 203 mean climatology of nutrient data averaged within the box ABCD showed that the $1 \mu$ mole 204 nitrate concentration was situated at a depth of $\sim 5 \mathrm{~m}$ during November (World Ocean Atlas 2005 205 data, ftp://ftp.nodc.noaa.gov/pub/data.nodc/woa/WOA05nc/monthly/) while the mixed layer 206 depth (MLD) during the same period was $\sim 25 \mathrm{~m}$ (de Boyer Montegut et al., 2004). From the 207 available Argo data (http://www.nodc.noaa.gov/argo/basins_data.htm) during the first fortnight 208 of November we could identify a float with ID R2901105 which was the closest to the Phyan 209 track, about 100-170 Km away to the left of cyclone track. The MLD computed from the Argo 210 data showed a deepening from $25 \mathrm{~m}$ on $5^{\text {th }}\left(70.36^{\circ} \mathrm{E}, 15.89^{\circ} \mathrm{N}\right)$ to $30 \mathrm{~m}$ on $9^{\text {th }}\left(70.34^{\circ} \mathrm{E}, 15.78^{\circ} \mathrm{N}\right)$ 211 November, consistent with the deepening seen from the November climatology. Earlier it was 212 shown that the strong upward Ekman pumping velocity of above $2 \times 10^{-4} \mathrm{~m} / \mathrm{s}$ (see Figure 3) driven 213 by the cyclonic wind-stress curl associated with Phyan could produce a cold pool with 214 temperature of about $27.5^{\circ} \mathrm{C}$. From the Argo temperature profile it was found that the $27.5^{\circ} \mathrm{C}$ 215 isotherm (coolest surface temperature depicted by satellite near the track) was located at $\sim 58 \mathrm{~m}$ 216 depth. For a given vertical velocity of $2 \times 10^{-4} \mathrm{~m} / \mathrm{s}$ it would take about 3.4 days for nutrients to 217 come to surface from about $60 \mathrm{~m}$. Thus, the observed enhanced chlorophyll $a$ biomass after 3-4 218 days of passage of cyclone could be explained in the context of prevailing cyclonic winds and 219 the associated upward pumping of nutrients.

220 Once the cyclone passes away and the cloudy sky clears off, the availability of sunlight and 221 nutrients will lead to an enhanced biological productivity. This has been explored in the 222 following section. 
Estimation of primary production is required to understand the biological process affecting

\section{7}

228

229

\subsection{Effect on $\mathrm{CO}_{2}$ flux} global biogeochemical cycles. Phytoplankton is the dominant primary producer in the marine environment, which synthesises organic material using nutrients, carbon dioxide and light energy with the help of chlorophyll through photosynthesis. We have seen a distinct increase of chlorophyll $a$ after the passage of Phyan. The Net Primary Production (NPP) was estimated from the codes of Vertically Generalised Productivity Model (VGPM) (Behrenfeld and Falkoswski, 1997), using the 3-day composite values of surface chlorophyll $a$ concentration from MODIS Aqua, Sea-viewing Wide Field-of-view Sensor (SeaWiFs) daily Photosynthetically Available Radiation (PAR) and optimally interpolated TMI-MODIS-AMSRE SST during 7-17 November 2009. The spatial averaged NPP within the box ABCD is presented in figure 5. The NPP in the eastern Arabian Sea before the occurrence of Phyan was $\sim 650 \mathrm{mg} \mathrm{C} \mathrm{m}^{-2}$ day $^{-1}$ and it showed a rapid increase to $\sim 1050 \mathrm{mg} \mathrm{C} \mathrm{m}^{-2}$ day $^{-1}$ on $12^{\text {th }}$ November immediately after the dissipation of the cyclone. The peak NPP value of $\sim 1350 \mathrm{mg} \mathrm{C} \mathrm{m}^{-2}$ day $^{-1}$ was attained on $16^{\text {th }}$ November, 4 days after the cyclone event in agreement with increase in chlorophyll biomass. Thus, the observed 2fold increase in the NPP resulted from the new production which in turn was mediated by the process of upward Ekman pumping associated with the cyclone. A similar value of new production ( $1500 \mathrm{mg} \mathrm{C} \mathrm{m}^{-2}$ day $^{-1}$ ) was reported by Hema Naik et al. (2008), based on a chance in situ measurement of chlorophyll and nitrate and using Redfield ratio during a cyclone in Arabian Sea in December 1998. This indicated that the sporadic cyclonic storm in the Arabian Sea, which is showing an increasing trend in recent years (Prasanna Kumar et al., 2009) could support much higher primary productivity in a region which is known for its seasonally high phytoplankton blooms and biological productivity. The elevated primary production will exert additional pressure on already existing OMZ in the Arabian Sea leading to severe anoxic conditions (Naqvi et al., 2000). In addition, the upward Ekman pumping of subsurface cold water could also result in the enhancement and saturation of surface $\mathrm{pCO}_{2}$ which would finally lead to out gassing of $\mathrm{CO}_{2}$. This is explored in the following section. 
The intense biological activity in the Arabian Sea results in higher sea water $\mathrm{pCO}_{2}$ than in the

256 atmosphere for all seasons (Sarma et al., 1998), which makes the Arabian Sea a source of $\mathrm{CO}_{2}$ to

257 the atmosphere (Goyet et al., 1998; Sarma et al., 1998; Sabine et al., 2000). The sporadic cyclone

258 has the potential to intensify this source. The rate of exchange of sea-air $\mathrm{CO}_{2}$ depends on the

259 solubility of $\mathrm{CO}_{2}$ in sea water, gas transfer velocity and difference in partial pressure between the

260 Surface Ocean and atmosphere. We can formulate the net $\mathrm{CO}_{2}$ flux $(F)$ as:

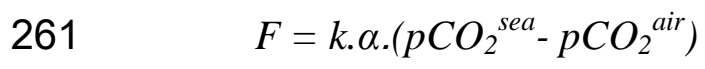

262 where $k$ is gas transfer velocity and $\alpha$ is the solubility of $\mathrm{CO}_{2}$ in sea water. The solubility $(\alpha)$ of

$263 \mathrm{CO}_{2}$ in sea water depends on surface temperature $(T)$ and salinity $(S)$ (Weiss, 1974) as

$$
\ln \alpha=A_{1}+A_{2}(100 / T)+A_{3} \operatorname{In}(T / 100)+S\left[B_{1}+B_{2}(T / 100)+B_{3}(T / 100)^{2}\right]
$$

265 The transfer velocity $(k)$ is determined from wind speed (Wanninkhof, 1992) as given below,

$$
k\left(\mathrm{~cm} \mathrm{~h}^{-1}\right)=I . U^{2} .(S c / 660)^{-1 / 2}
$$

where $U$ is the wind speed and the value of scaling factor $I=0.26$ was taken from Takahashi et al., (2009b). Sc is Schmidt number (kinematic viscosity of water / diffusion coefficient of $\mathrm{CO}_{2}$ in water) which is 660 for $\mathrm{CO}_{2}$ in seawater at $20^{\circ} \mathrm{C}$. Sc is a function of temperature $(T)$ and is given 270 by

$$
S c=A-B T+C T^{2}-D T^{3}
$$

272 Refer Weiss (1974) and Wanninkhof (1992) for the values of the constants $A, B, C$ and $D$.

273 We calculated the total $\mathrm{CO}_{2}$ flux associated with Phyan within the box ABCD in the eastern 274 Arabian Sea $\left(10^{\circ} \mathrm{N}-18^{\circ} \mathrm{N}\right.$ and $\left.70^{\circ} \mathrm{E}-75^{\circ} \mathrm{E}\right)$ using (1).

275 Studies have shown that though the surface ocean cools under the influence of cyclone, strong 276 wind associated with cyclone can intensify out-gassing of $\mathrm{CO}_{2}$ from ocean to atmosphere (Bates 277 et.al., 1998). A recent time series observation using moored buoy data in the East China Sea by 278 Nemeto et al. (2009) also suggested a similar result that strong wind and dissolved inorganic 279 carbon (DIC) supply from the subsurface during the passage of a cyclone can increase efflux of $280 \mathrm{CO}_{2}$ from ocean to atmosphere.

281 The $\mathrm{CO}_{2}$ flux to the atmosphere associated with Phyan over the eastern Arabian Sea $\left(10^{\circ} \mathrm{N}\right.$ $28218^{\circ} \mathrm{N}$ and $\left.70^{\circ} \mathrm{E}-75^{\circ} \mathrm{E}\right)$ during $8^{\text {th }}$ to $11^{\text {th }}$ November was about $0.123 \mathrm{Tg} \mathrm{C}\left(1 \mathrm{Tg}=10^{12} \mathrm{~g}\right.$ ) (Figure 6), 283 which accounted for $\sim 85 \%$ of the total out-gassing of $\mathrm{CO}_{2}$ for the month of November 284 (climatology) calculated by Takahashi et al. (2009a). The total emission of $\mathrm{CO}_{2}$ during 285 November 2009 was $\sim 0.244 \mathrm{Tg} \mathrm{C}$, which was about $170 \%$ of the climatological value $(0.144 \mathrm{Tg}$ 286 C) over the area ABCD (see Figure1 for location of box). Based on the Indian JGOFS 287 measurements Sarma et al. (1998) estimated the seasonal variability of $\mathrm{CO}_{2}$ emission to be 1 to 
$2883.5 \mathrm{mmol} \mathrm{m}^{-2} \mathrm{day}^{-1}$ (excluding south west monsoon period) (Sarma et al., 1998). The present

289 estimate showed that during the course of cyclone Phyan $\sim 8 \mathrm{mmol} \mathrm{m}^{-2}$ day $^{-1} \mathrm{CO}_{2}$ was emitted

290 from ocean to atmosphere, making the eastern Arabian Sea a major source.

\section{Conclusion}

In this study we investigated the impact of tropical cyclone Phyan to the ocean biology and $\mathrm{CO}_{2}$ exchange over the eastern Arabian Sea using in situ as well as remote sensing data sets. Surface temperature showed an immediate response by way of cooling $\left(2^{\circ} \mathrm{C}\right)$ while chlorophyll $a$ and net primary production showed a delayed response. The strong wind-mixing associated with cyclonic winds led to the observed rapid cooling, which was sustained even after the dissipation of Phyan by the wind-stress curl induced upward Ekman pumping. Though the SST showed an immediate response, the biological response to Phyan showed a time lag. The peak chlorophyll $a$ and the net primary productivity (NPP) occurred 3-4 days after the dissipation of Phyan. The chlorophyll $a$ showed an average enhancement of $0.5 \mathrm{mg} / \mathrm{m}^{3}$ while the NPP showed a two-fold increase. The mechanism that supported increased biological productivity was the vertical transport of subsurface nutrients by the wind stress curl. The upward Ekman pumping transported the cold and nutrient rich waters to the upper ocean which was also enriched in $\mathrm{CO}_{2}$. The estimated $\mathrm{CO}_{2}$ flux to the atmosphere associated with Phyan was $0.123 \mathrm{Tg} \mathrm{C}$ which was $85 \%$ of the climatological monthly mean value for November. The above results of our study have implication to the Arabian Sea which already has a mid-depth OMZ. Thus, in the Arabian Sea the increased frequency and intensity of the cyclones in a warming environment are expected to increase manifold the biological productivity as well as $\mathrm{CO}_{2}$ out-gassing. Increased productivity, in turn, will exert increased demand on mid-depth oxygen exerting additional stress on already existing OMZ.

\section{Acknowledgements}

315 The authors wish to acknowledge Director, National Institute of Oceanography (NIO), Goa as

316 well as Council of Scientific and Industrial Research (CSIR), New Delhi for all the support and

317 encouragement for the successful completion of this work. The funding support of Ministry of 318 Earth Sciences (MoES) through Centre for Marine Living Resources and Ecology (CMLRE), 319 Kochi for the project "Assessment of Myctophid resources in the Arabian Sea" is gratefully 320 acknowledged. This in NIO contribution Number xxxx. 


\section{References}

323 Bates, N.R., Knap, A.H. and Michaels, A.F., 1998. Contribution of hurricanes to local and global

324 estimates of air-sea exchange of $\mathrm{CO}_{2}$, Nature 395, 58-61.

325

326 Behrenfeld, M.J., Falkoswski, P.G., 1997. Photosynthetic rates derived from satellite based

327 chlorophyll concentration, Limnology and Oceanography 42(1), 1-20.

328

329 de Boyer Montegut, C., Madec, G., Fischer, A.S., Lazar, A., Iudicone, D., 2004. Mixed layer

330 depth over the global ocean: an examination of profile data and a profile-based climatology,

331 Journal of Geophysical Research 109, C12003. doi:10.1029/2004JC002378.

333 DeMaria M., Kaplan, J., 1994. Sea surface temperature and the maximum intensity of 334 Atlantic tropical cyclones, Journal of Climate 7, 1325-1334.

336 Dube, S.K., Rao, A.D., Sinha, P.C., Murty, T.S., Bahuleyan N., 1997. Storm surge in Bay of 337 Bengal and Arabian Sea: The problem and its prediction, Mausam 48, 288-304.

339 Emanual, K.A., 2005. Increasing destructiveness of tropical cyclone over the past 30 years, 340 Nature 326, 686-688.

342 Goes, J.I., Thoppil, P.G., Gomes, H.R., Fasullo, J.T., 2005. Warming of the Eurasian landmass is 343 making the Arabian Sea more productive, Science 308, 545-547.

345 Goyet, C., Millero, F.J., O’Sullivan, D.W., Eischeid, G., McCue, S.J., Bellerby, R.G.J., 1998. 346 Temporal variations of $\mathrm{pCO}_{2}$ in surface seawater of the Arabian Sea in 1995, Deep Sea Research 347 II 45, 609-624.

349 Gray, W.M., 1979. Hurricanes: Their formation, structure and likely role in the tropical 350 circulation, in: D. B. Shaw (Ed.), Meteorology over the tropical oceans, Royal Meteorological 351 Society, James Glaisher House, Grenville Place, Bracknell, Berkshire, RG121BX, 155-218. 
353 Hema Naik, Naqvi, S.W.A., Suresh, T., Narvekar, P.V., 2008. Impact of tropical cyclone on

354 biogeochemistry of the central Arabian Sea, Global Biogeochemical Cycles 22, GB3020. Doi:

$35510.1029 / 2007$ GB003028.

356

357 Joseph, A., Prabhudesai, R.G., Mehra, P., Sanil Kumar, V., Radhakrisnan, K.V., Kumar, V., Ashok

358 Kumar, K., Agarwadekar, Y., Bhat, U.G., Luis, R., Rivankar, P., Viegas, B., 2010. Response of 359 west Indian coastal regions and Kavaratti lagoon to the November-2009 tropical cyclone Phyan,

360 Natural Hazards, DOI: 10.1007/s11069-010-9613-7.

361

362 Lin, I., Liu, W.T., Wong, C.C., Hu, G.T.F., Chen, C., Liang, Z., Liang, W.D., Yang, Y., Liu, K.K., 363 2003. New evidence for enhanced ocean primary production triggered by tropical cyclone, 364 Geophysical Research Letters 30, 1718. doi:10.1029/2003GL017141.

365

366 Madhu, N.V., Maheswaran, P.A., Jyothibabu, R., Revichandran, C., Balasubramanian, T., 367 Gopalakrishnan, T.C., Nair, K.K.C., 2002. Enhanced biological production off Chennai triggered 368 by October 1999 super cyclone (Orissa), Current Science 82, 1472-1479.

369

370 Naqvi, S.W.A., Jayakumar, D.A., Narvekar, P.V., Naik, H., Sarma, V.V.S.S., D’Souza, W., 371 Joseph, S., George, M.D., 2000. Increased marine production of $\mathrm{N}_{2} \mathrm{O}$ due to intensifying 372 anoxia on the Indian continental shelf, Nature 408, 346-349.

373

374 Nemoto, K., Midorikawa, T., Ogawa, A., Takatani, S., Kimoto,H., Ishii, M., Inoue, H.Y., 2009.

375 Continuous observations of atmospheric and oceanic $\mathrm{CO}_{2}$ using a moored buoy in the East China 376 Sea: Variations during the passage of typhoons, Deep Sea Research II 56, 542-553.

378 Prasanna Kumar, S., Prasad, T.G., 1996. Winter cooling in the northern Arabian Sea, Current 379 Science 71, 834-841.

381 Prasanna Kumar, S., Roshin, R.P., Narvekar, J., Dinesh Kumar, P.K., Vivekanandan, E., 2009.

382 Response of the Arabian Sea to global warming and associated regional climate shift, Marine 383 Environmental Research 68, 217-222. 
385 Prasanna Kumar, S., Roshin, R.P., Narvekar, J., DineshKumar, P.K., Vivekanandan, E., 2010.

386 Signatures of global warming and regional climate shift in the Arabian Sea, in: Joseph, A.,

387 Nandan, S.B., Augustine, A. (Eds.), Climate change and aquatic ecosystems, Natl. Symp. On

388 Impact Climate Change on Aquatic Ecosystems (NSICCAE 2010), Cochin, India, 55-62.

390 Price, J.F., 1981. Upper ocean response to hurricane, Journal of Physical Oceanography 11, 153391175.

392

393 Pudov, V.D., 1992. The oceans response to the cyclone's influence and its possible role in their 394 track formation, In: Proc. ICSU/WMO Int. Symp. On Tropical Cyclone Disasters, Beijing, 395 China, WMO, 367-376.

396

397 Rao, K.H., Smitha, A., Ali, M.M., 2006. A study on cyclome induced productivity in south398 western Bay of Bengal during November-December 2000 using MODIS (SST and chlorophyll399 a)and altimeter sea surface height observations, Indian Journal of Marine Science 35(2), 153400160.

401

402 RupaKumar, R., KrishnaKumar, K., Ashrit, R.G., Patwardhan, S.K., Pant, G.B., 2002. Climate 403 change in India: observations and model projections, In: Shukla, P.R.,Sharma, S.K., Venkata 404 Ramana, P., (Eds.), Climate Change and India: Issues, Concerns and Opportunities, 405 TataMcGraw-Hill Publishing Company Limited, New Delhi.

407 Sabine, C.L., Wanninkhof, R., Key, F.M., Goyet, C., Millero, F.J., 2000. Seasonal $\mathrm{CO}_{2}$ fluxes in 408 the tropical and subtropical Indian Ocean, Marine Chemistry 72, 33-53.

410 Sadhuram, Y., 2004. Record decrease of sea surface temperature following the passage of a super 411 cyclone over the Bay of Bengal, Current Science 86, 383-384.

413 Sarma, V.V.S.S., Kumar, M.D., George, M.D., 1998. The central and eastern Arabian Sea as a 414 perennial source for atmospheric carbon dioxide, Tellus Series B 50, 179-184. 
416 Subrahmanyam, B., Rao, K.H., Rao, N.S., Murty, V.S.N., 2002. Influence of a tropical cyclone

417 on chlorophyll a concentration in the Arabian Sea, Geophysical Research Letters 29(22), 2065.

418 doi:10.1029/2002GL015892.

419

420 Takahashi, T., Sutherland, S.C., Kozyr, A., 2009a. Global Ocean Surface Water Partial Pressure

421 of $\mathrm{CO}_{2}$ Database: Measurements Performed During 1968-2008 (Version 2008). ORNL/CDIAC-

422 52, NDP-088r. Carbon Dioxide Information Analysis Center, Oak Ridge National Laboratory,

423 U.S. Department of Energy, Oak Ridge, Tennessee. doi: 10.3334/CDIAC/otg.ndp088r.

424

425 Takahashi, T., Sutherland, S.C., Wanninkhof, R., Sweeney, C., Feely, R.A., Chipman, D.W.,

426 Hales, B., Friederich, G., Chavez, F., Watson, A., Bakker, D.C.E., Schuster, U., Metzl, N.,

427 Yoshikawa- Inoue, H., Ishii, M., Midorikawa, T., Nojiri, Y., Sabine, C., Olafsson, J., Arnarson,

428 Th.S., Tilbrook, B., Johannessen, T., Olsen, A., Richard Bellerby, Körtzinger, A., Steinhoff, T.,

429 Hoppema, M., de Baar, H.J.W., Wong, C.S., Bruno Delille, Bates, N.R., 2009b. Climatological

430 mean and decadal changes in surface ocean $\mathrm{pCO}_{2}$, and net sea-air $\mathrm{CO}_{2}$ flux over the global

431 oceans, Deep-Sea Research II 56, 554-577.

432

433 Trenberth, K.E., 2005. Uncertainty in hurricanes and global warming, Science 308, 1753-1754.

435 Wanninkhof, R., 1992. Relationship between wind speed and gas exchange over the ocean, 436 Journal of Geophysical Research 97, 7373-7382.

438 Webster, P.J., Holland, G.J., Curry, J.A., Chang, H.R., 2005. Changes in tropical cyclone number, 439 duration, and intensity in a warming environment, Science 309, 1844-1846.

441 Weiss, R.F., 1974. Carbon dioxide in water and seawater: the solubility of a non-ideal gas, 442 Marine Chemistry 2, 203-215.

\section{Legend to figures}

446 Fig. 1. Track of the cyclone Phyan (black line) over the Arabian Sea during $09^{\text {th }}$ to $11^{\text {th }}$

447 November 2009. Shading and the filled contours are SST averaged during the above period. Box 
448 ABCD denotes the area influenced by the cyclone while box EFGH indicates the location of the

449 cold pool. Blue patches are waters colder than $27.5^{\circ} \mathrm{C}$, seen during cyclone period to the right of 450 the cyclone track.

451 Fig. 2. Time evolution of SST along the track (see Figure 1 for location) before, during and after

452 the passage of cyclone Phyan. A drop in SST by $\sim 2^{\circ} \mathrm{C}$ between $12^{\circ} \mathrm{N}$ and $13^{\circ} \mathrm{N}$ occurred on $10^{\text {th }}$

453 November.

454 Fig. 3. Time evaluation of wind-stress curl (red), Ekman-pumping velocity (green), 2009 SST

455 (blue) and SST climatology (black dash line) at the cold pool location EFGH $\left(12.5^{\circ} \mathrm{N}-13^{\circ} \mathrm{N}\right.$,

$45671^{\circ} \mathrm{E}-72^{\circ} \mathrm{E}$ ) indicated in Figure 1. The SST climatology is from TMI during 1998-2009.

457 Fig. 4. Time series of 3-day composite (centred at the mid-point) of MODIS Aqua derived

458 surface chlorophyll (black) distribution averaged within the box $\mathrm{ABCD}$ (longitude $70^{\circ} \mathrm{E}-75^{\circ} \mathrm{E}$

459 and latitude $10^{\circ} \mathrm{N}-18^{\circ} \mathrm{N}$; see Fig.1). The red coloured plot indicates the number of data pixels that

460 were actually used for the determination of chlorophyll expressed in percentage. Low values of

461 pixel percentage indicate overcast sky and less number of data points for the computation of 462 chlorophyll.

463 Fig. 5. Net primary production (NPP) values in $\mathrm{mg} \mathrm{C} \mathrm{m}^{-2}$ day $^{-1}$ averaged within the box ABCD 464 (longitude $70^{\circ} \mathrm{E}-75^{\circ} \mathrm{E}$ and latitude $10^{\circ} \mathrm{N}-18^{\circ} \mathrm{N}$ ).

465 Fig. 6. Total carbon dioxide flux in $\operatorname{Tg} \mathrm{C}\left(1 \mathrm{Tg}=10^{12} \mathrm{~g}\right) \mathrm{m}^{-2}$ day $^{-1}$ integrated over the box ABCD 466 (see Figure 1 for the location). * $\mathrm{T} \mathrm{CO}_{2}$ values are from Takahashi et al.,(2009a). 
Impact of tropical cyclone was immediate $2^{\circ} \mathrm{C}$ SST-cooling due to strong wind-mixing

Biological response was 2-fold increase in productivity with 3-4 days lag time

Upward Ekman-pumping and associated nutrient transport enhanced chlorophyllbiomass

- Increased $\mathrm{CO}_{2}$ out-gassing of $0.123 \mathrm{Tg}$ accounts for $85 \%$ November climatology 

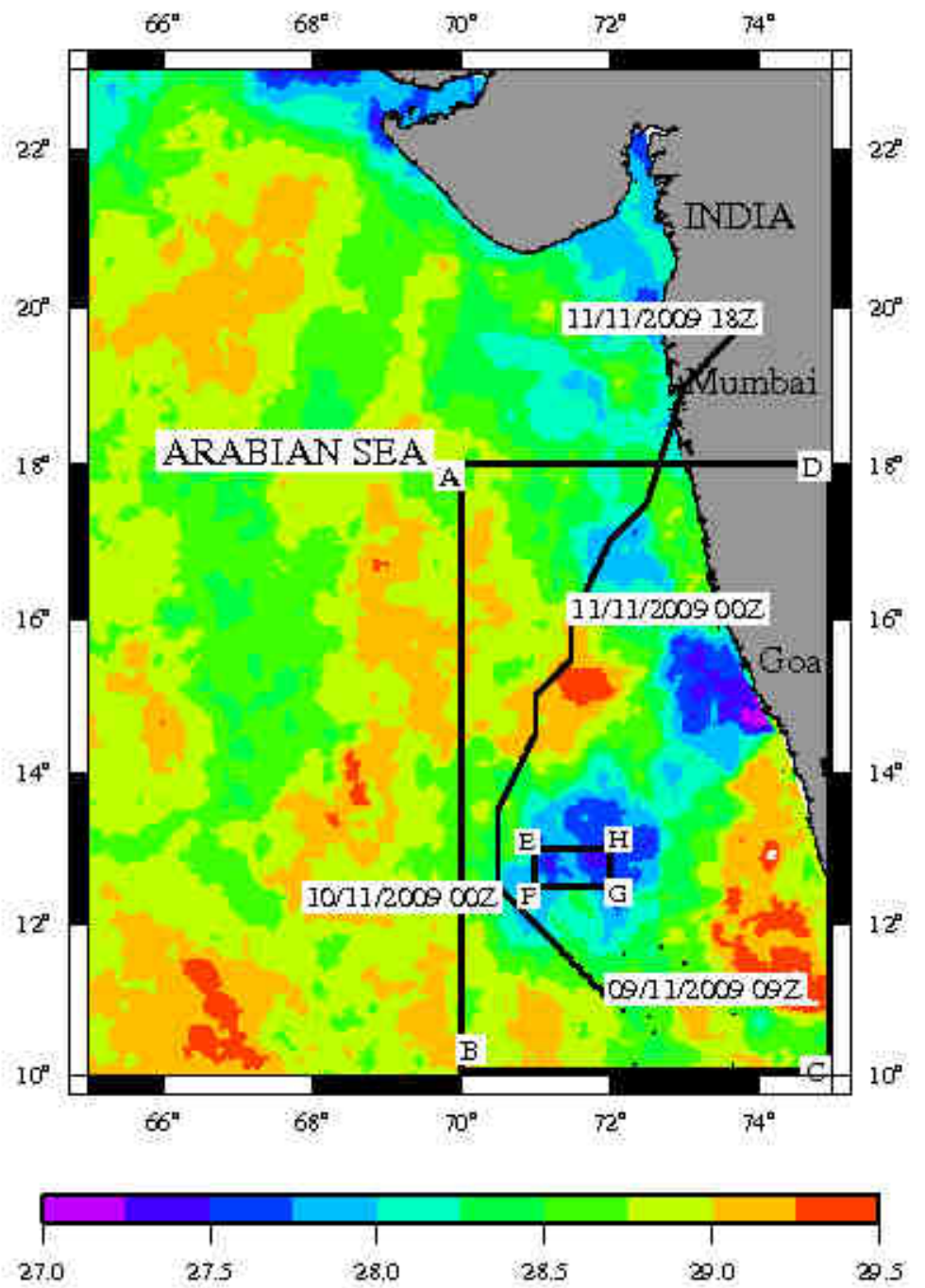

Sea Surface Temperature in ${ }^{\circ} \mathrm{C}$ 


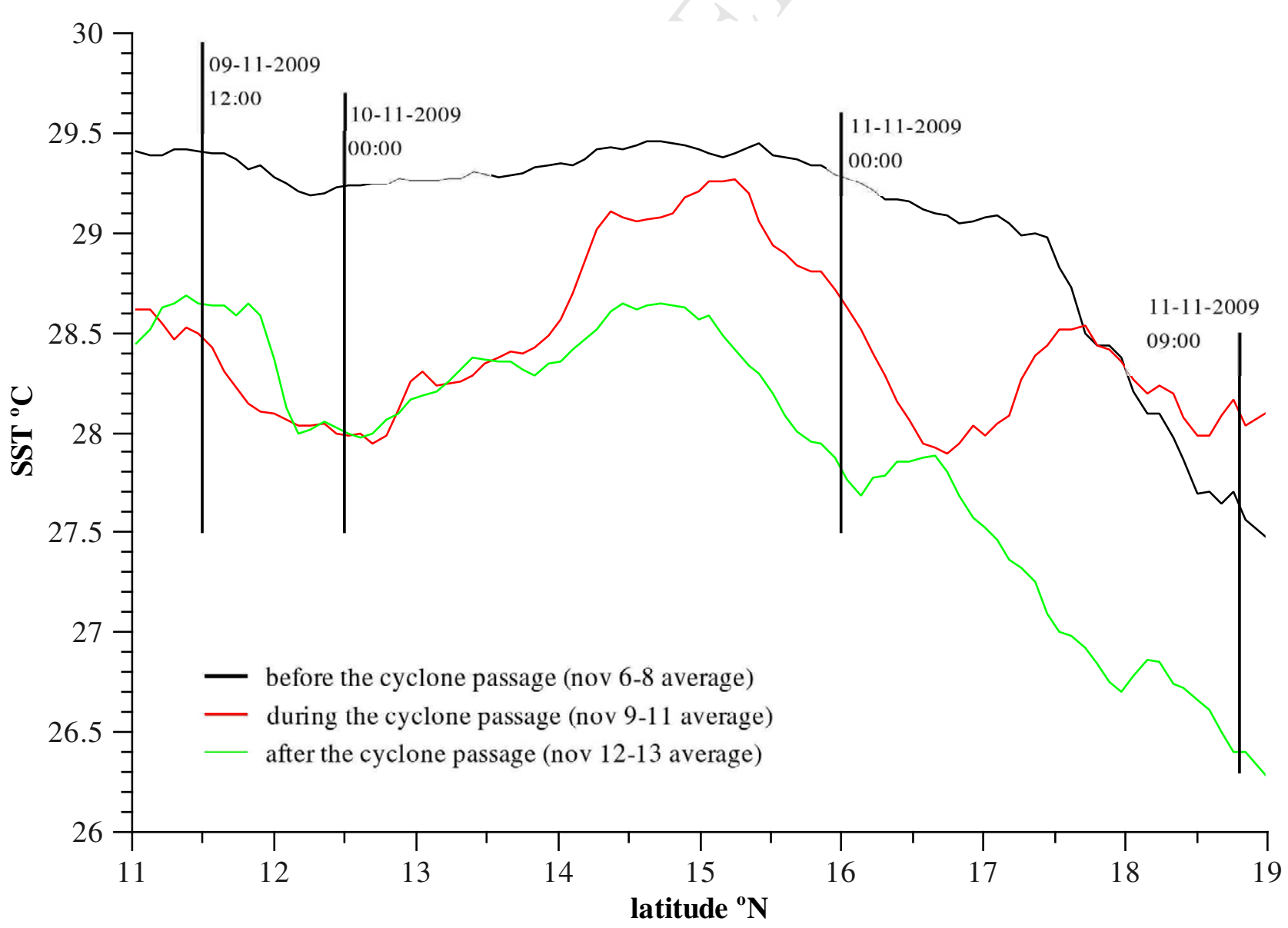




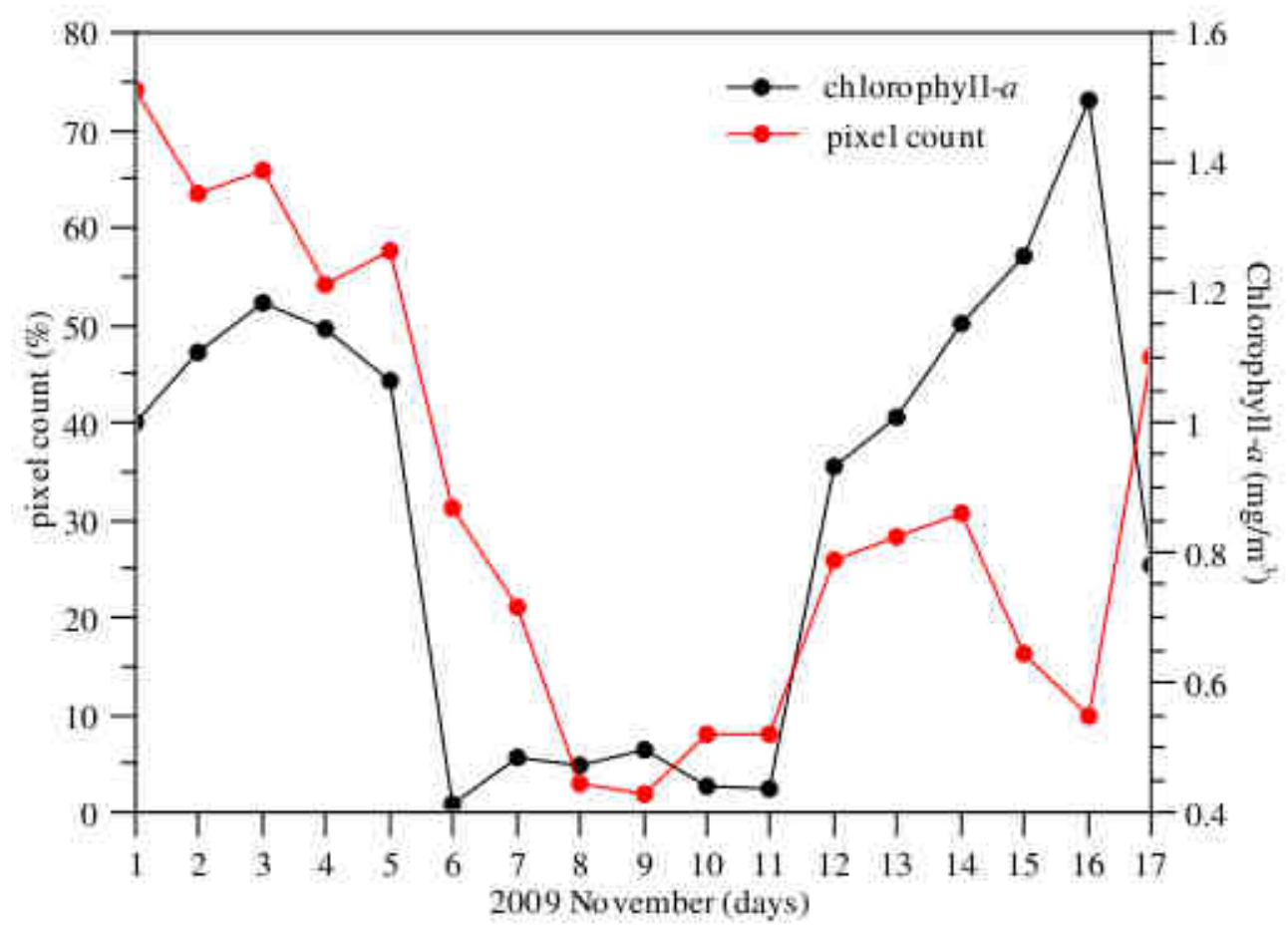




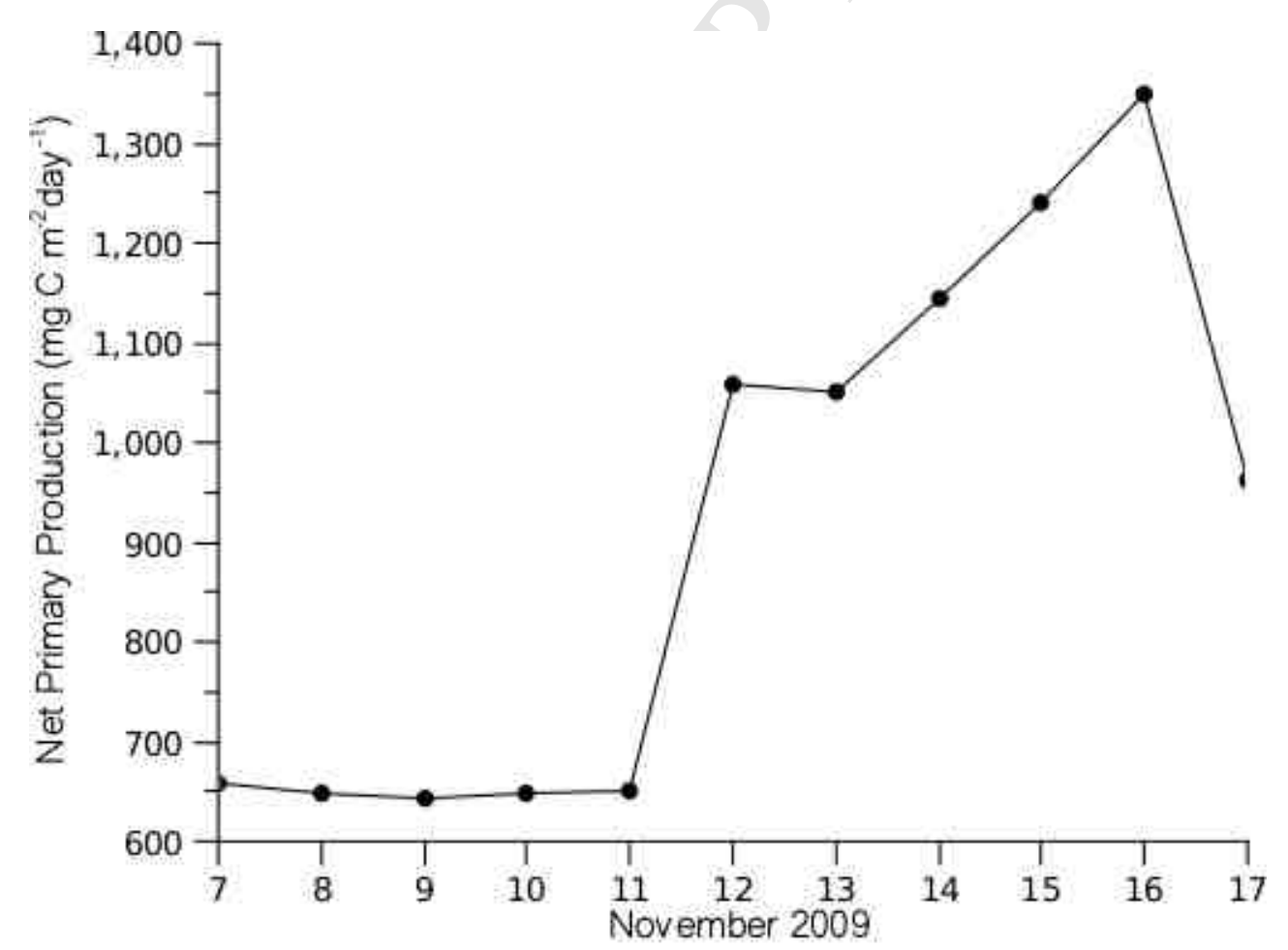




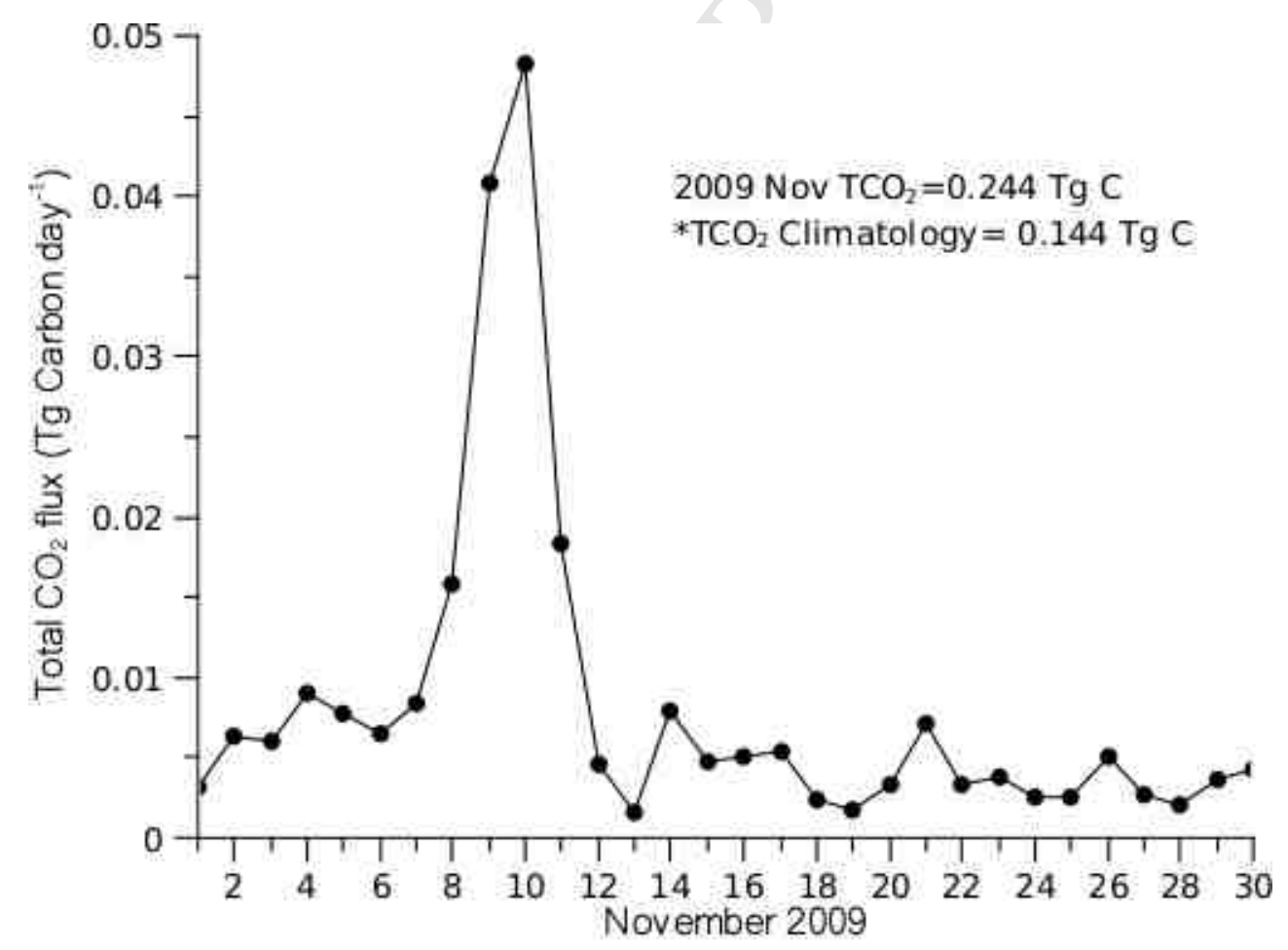

